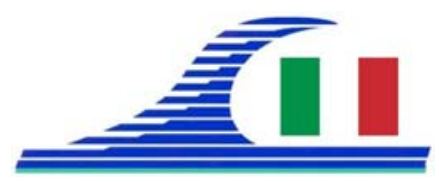

Conférence Méditerranéenne Côtière et Maritime EDITION 3, FERRARA, ITALIA (2015)

Coastal and Maritime Mediterranean Conference

Disponible en ligne - http://www.paralia.fr - Available online

\title{
Sediment's vitrification from industrial sites and their reuse as secondary raw materials for mineral wool production
}

\author{
Sergio CAPPUCCI ${ }^{1}$, Floriana LA MARCA ${ }^{2}$, Roberto FALCONE ${ }^{3}$, \\ Nicole FABRIZIO ${ }^{2}$, Silvia DE POL $^{3}$
}

1 ENEA, Via Anguillarese, 301, 3 - 00123 Roma, Italy.

sergio.cappucci@enea.it

2. University of Rome "La Sapienza", Italy.

floriana.lamarca@uniroma1.it;nicolefabrizio@libero.it

3. Stazione Sperimentale del Vetro (SSV), Venezia - Murano, Italy.

rfalcone@spevetro.it

\begin{abstract}
:
The results of a vitrification test carried out on potentially contaminated sediment samples collected in different Italian coastal areas (Lazio, Sardinia, and Tuscany Regions) are presented. One sample has physical and chemical properties compatible with reuse for production of industrial hollow glass. Other three samples were selected and mixed in a batch simulating a composition close to that of mineral wool products. The results of the present investigation indicate that the inertization of these hazardous material is possible and their reuse as secondary raw material for the production of mineral wool is achievable and likely sustainable.
\end{abstract}

Keywords: Sediment management, Contamination, Vitrification, Raw materials.

\section{Introduction}

The potentially contaminated sites were surveyed by the Italian Regional Authorities according to DM 185/99 and from the sites requiring remediation established by Ministerial Decree 471/99. To date, the sites to be reclaimed are about 5,000 , or $38 \%$ of the 13,000 sites potentially contaminated, of which 12,943, in many cases of limited extension, are under competence of the Region Authorities (SIR). There are also 57 sites of national interest (SIN) that covers more than 3\% of the country's area, including a total of 821,000 ha of land areas and nearly 340,000 ha of sea areas (Fig. 1). About $50 \%$ of contaminated sites falls along coastal areas and Northern Italy. The main source of contamination (69\%) is related to industrial and production activities in the chemicalpetrochemical-metallurgical-mechanical-shipbuilding-energy sectors, followed by uncontrolled abandonment of wastes (29\%). Remediation of contaminated sediments is a theme, increasingly addressed by the scientific community (CAPPUCCI et al., 2011), especially in harbour areas where the quantitative assessment of potentially contaminated sediment is becoming a challenging scientific issue (AUSILI et al., 2012). 
Côtes méditerranéennes menacées :

Risques et défis dans le contexte du changement climatique
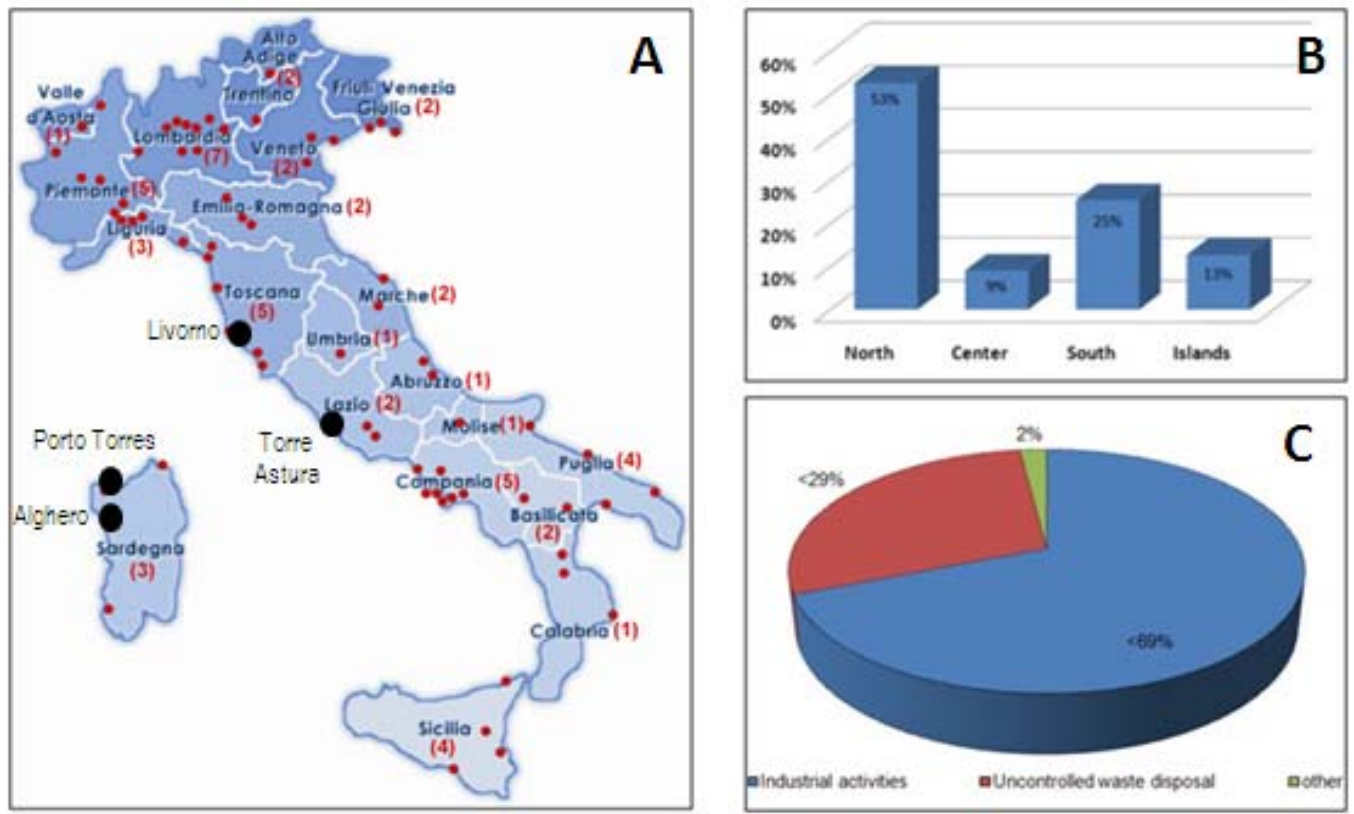

Figure. 1. Distribution of the 57 contaminated sites of national interest (A), their geographic distribution (B) and the main source of contamination (C).

\section{Materials and Methods}

A detailed description of the methodology used in the present research is reported in the work of FABRIZIO (2014) and is synthetically described as follow.

\subsection{Delimitation of sedimentary provinces}

The first phase of the work consisted in identification of the sampling sites. All information regarding the geological, sedimentological, morphological and historical information related to coastal characteristics have been consulted from the "Italian Atlas of Beaches".

\subsection{The studied sites}

Once the location and extent of each sedimentary province was determined along the Italian coast, the selection of sampling sites were chosen following these criteria: (a) presence of sediments with a quartz or silica content greater than 40\%; (b) presence of a contaminated site of national interest and; (c) possible or imminent dredging of an harbor and/or possible contamination of the sediment by human activities.

Two sampling sites were chosen in coastal marine areas adjacent or included in the Reclamation Sites of National Interest (SIN; Porto Torres in Sardinia and Livorno in Tuscany). Other two sites were selected where local land use planning involves the construction of new port facilities (Astura, Latium) or the expansion of existing ones (Alghero, Sardinia). 


\subsection{Physical, mineralogical and chemical analysis}

Sediments were wet and dry sieved and grain size distributions were determined both gravimetrically and by using the Coulter ${ }^{\circledR}$ Laser counter. The chemical and mineralogical compositions were assessed by WDXRF, XRD and SEM/EDX analysis. Inorganic contaminants were detected by means of both ICP-AES and ACP-MS analysis and SEM/EDX investigation.

\subsection{Preparation of an ingot}

Three samples (from Livorno, Torre Astura and Alghero), out of four, were selected and mixed in a batch simulating a composition close to that of mineral wool products. About $1 \mathrm{~kg}$ of the batch was melted in an electric furnace at a maximum temperature $1400{ }^{\circ} \mathrm{C}$ for 4 hours, casted in a steel plate and annealed at $550{ }^{\circ} \mathrm{C}$. A homogeneous dark glass was produced. A leaching test was performed according to the UNI EN 1245-2 and it was classified as inert material.

\section{Results}

Many results were obtained but only part of them will be presented in Table 1, 2 and 3. One sandy sample (from Porto Torres) has physical and chemical properties that suggest its possible reuse as silica sand raw material for production of industrial hollow glass. Three samples, out of four, can be considered representative of hazardous/toxic waste in case of removal of the sediment from the seafloor, requiring expensive disposal in hazardous waste landfill by using standard management solution. They were selected and mixed in a batch simulating a composition close to that of mineral wool products. The chemical composition of the produced dark glass (Fig. 2) was compared with the calculated theoretical one (Table ). A leaching test was performed according to the UNI EN 1245-2 norm and the obtained "glass" was classified as inert material.

Table 1. Grain size distribution of sediment samples and classification.

\begin{tabular}{llllll} 
Sieve & Sample Name & & & & Sediment \\
\hline & Porto Torres & Alghero & Torre Astura & Livorno & \\
\hline$(\mathrm{mm})$ & $(\mathrm{g})$ & $(\mathrm{g})$ & $(\mathrm{g})$ & $(\mathrm{g})$ & \\
\hline 4,000 & 5,110 & 0,000 & 0,000 & 0,000 & \\
2,000 & 34,520 & 0,240 & 0,070 & 5,559 & Gravel \\
1,000 & 329,970 & 0,980 & 0,060 & 1,690 & \\
\hline 0,500 & 170,850 & 15,510 & 78,150 & 2,141 & \\
0,250 & 1,030 & 311,180 & 255,880 & 2,467 & \multirow{2}{*}{ Sand } \\
0,125 & 0,290 & 91,320 & 58,150 & 2,331 & \\
0,075 & 0,100 & 0,440 & 0,410 & 1,711 & \\
\hline & & & 0,000 & \multirow{2}{*}{ Silt } \\
& & & 13,405 & \multirow{2}{*}{ Clay } \\
\hline
\end{tabular}


Côtes méditerranéennes menacées :

Risques et défis dans le contexte du changement climatique

Table 2. Bulk chemical composition of sediment samples. Concentrations are reported both in weight \% and ppm (according to prescription of Italian environmental national law for contaminated sites*).

\begin{tabular}{|c|c|c|c|c|}
\hline & Porto Torres & Alghero & Torre Astura & Livorno \\
\hline Oxides & Wt. \% & Wt. \% & Wt. \% & Wt. \% \\
\hline $\mathrm{SiO}_{2}$ & 90.5 & 59.4 & 43.0 & 55.6 \\
\hline $\mathrm{TiO}_{2}$ & 0.04 & 0.11 & 2.35 & 0.76 \\
\hline $\mathrm{Al}_{2} \mathrm{O}_{3}$ & 3.40 & 5.90 & 7.10 & 17.2 \\
\hline $\mathrm{Fe}_{2} \mathrm{O}_{3}$ tot & 0.26 & 0.26 & 15.6 & 6.75 \\
\hline $\mathrm{MnO}$ & $<0.02$ & $<0.02$ & 0.32 & 0.09 \\
\hline $\mathrm{MgO}$ & 0.16 & 1.23 & 9.75 & 3.50 \\
\hline $\mathrm{CaO}$ & 3.10 & 30.1 & 20.6 & 10.1 \\
\hline $\mathrm{Na}_{2} \mathrm{O}$ & 0.80 & 1.97 & 0.50 & 2.73 \\
\hline $\mathrm{K}_{2} \mathrm{O}$ & 1.64 & 0.57 & 0.20 & 2.77 \\
\hline $\mathrm{P}_{2} \mathrm{O}_{5}$ & $<0.03$ & 0.04 & 0.16 & 0.22 \\
\hline $\mathrm{Cr}_{2} \mathrm{O}_{3}$ & $<0.02$ & $<0.02$ & 0.12 & 0.03 \\
\hline $\mathrm{SO}_{3} \mathrm{tot}$ & $<0.05$ & 0.24 & $<0.05$ & 0.11 \\
\hline $\mathrm{ZrO}_{2}$ & $<0.01$ & 0.01 & 0.15 & 0.02 \\
\hline $\begin{array}{l}\text { L.o.i Wt. } \\
\left(100^{\circ} \mathrm{C}-1000^{\circ} \mathrm{C}\right)\end{array}$ & 2.6 & 20.4 & 1.30 & 14.9 \\
\hline Metals & $\mathrm{mg} / \mathrm{kg} s \mathrm{~s}$ & $\mathrm{mg} / \mathrm{kg} s \mathrm{ss}$ & $\mathrm{mg} / \mathrm{kg} s \mathrm{ss}$ & $\mathrm{mg} / \mathrm{kg} \mathrm{ss}$ \\
\hline$A s^{*}$ & 7,32 & 3,35 & 3,63 & 15,8 \\
\hline$C d^{*}$ & 0,011 & 0,069 & 0,032 & 0,258 \\
\hline Cr tot* & 2,09 & 5,04 & 41,1 & 78,7 \\
\hline$C u^{*}$ & 4,37 & 4,61 & 19,9 & 53,4 \\
\hline $\mathrm{Hg}^{*}$ & 0,006 & $<0,01$ & $<0,01$ & 0,21 \\
\hline $\mathrm{Ni} *$ & 1,36 & 8,45 & 38,9 & 73,00 \\
\hline$P b^{*}$ & 1,67 & 4,22 & 19,6 & 29,50 \\
\hline $\mathrm{Zn}^{*}$ & 14,2 & 14,9 & 420 & 129 \\
\hline$V^{*}$ & 9,17 & 7,62 & 852 & 48,51 \\
\hline$A I$ & 0,05 & 0,14 & 0,86 & 1,39 \\
\hline $\mathrm{Fe}$ & $0,12 \%$ & 0,07 & 1,20 & 2,67 \\
\hline
\end{tabular}

Table 3. Mineralogical compositions.

\begin{tabular}{ll} 
Sample & Phase \\
\hline Alghero & Quartz \\
& Calcite \\
& Aragonite \\
& Plagioclase (anortite) \\
\hline Torre Astura & Pyroxenes (augites) \\
& Quartz \\
\hline Livorno & Quartz \\
& Calcite \\
& Illite/Muscovite \\
\hline
\end{tabular}


Table 4. Theoretical (TC) and analysed (AC) composition of produced glass compared to typical composition ranges of mineral wool (ERCOLE, 2012).

\begin{tabular}{llll}
\hline Wt. \% & TC & AC & $\begin{array}{l}\text { Typical mineral wool } \\
\text { composition ranges }\end{array}$ \\
\hline $\mathbf{S i O}_{2}$ & 50.7 & 49.0 & $38-57$ \\
$\mathbf{A l}_{2} \mathbf{O}_{3}$ & 10.4 & 10.5 & $0-23$ \\
$\mathrm{Na}_{2} \mathbf{O}$ & 1.57 & 1.13 & $0.5-5$ \\
$\mathbf{K}_{2} \mathbf{O}$ & 1.17 & 1.10 & \\
$\mathbf{M g O}$ & 5.86 & 6.00 & $18-40$ \\
$\mathbf{C a O}$ & 18.8 & 18.3 & \\
$\mathbf{T i O}_{2}$ & 1.35 & 1.54 & $0.5-4$ \\
$\mathbf{F e}_{2} \mathbf{O}_{3}$ tot & 9.43 & 11.7 & $0.5-12$ \\
$\mathbf{P}_{2} \mathbf{O}_{5}$ & 0.16 & 0.20 & $0-3$ \\
\hline
\end{tabular}

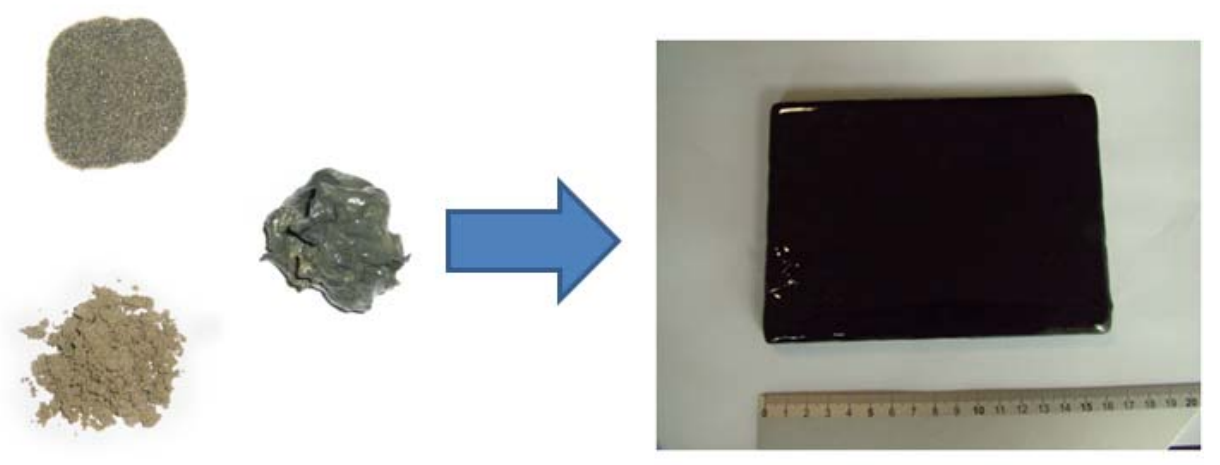

Fig. 2. Picture of black glass due to the dark sand and the presence of $\mathrm{Fe}_{2} \mathrm{O}_{3}$ and $\mathrm{MgO}$.

\section{Conclusions}

In all countries sediment management is becoming a relevant issue, particularly when the dredging of contaminated materials is needed for port maintenance. Supply of raw materials are also essential for national, European and world economy. Scarcity of raw materials coexists with a considerable increase of waste's production, the disposal of which, along with the over-exploitation of the land, is leading further environmental degradation. On the other hand, a widespread concern is related to the possibility of replacing a certain raw material with another one. Taking into account these two aspects, the present paper contributes to technological developments that allow a sustainable exploitation of known contaminated sedimentary bodies, providing a solution to both the long lasting dredging authorisation's procedure and the remediation within harbours.

The results of this preliminary investigation indicate that the inertization of hazardous sediment and the reuse as secondary raw material for the production of mineral wool is achievable. In particular, the recovery of contaminated sediments as a raw material for the production of glass for mineral wool industry has been proved by production of an 
Côtes méditerranéennes menacées :

Risques et défis dans le contexte du changement climatique

ingot of matter that would allow to produce samples of batches on a pilot plant. This product is facing an increasing interest of many countries (FABRIZIO et al., 2014). Nonetheless, further investigation and industrial scale tests are required in order to confirm the feasibility of the industrial implementation.

For this reason, in July 2014, the Italian Ministry of Economic Development (Directorate General for Industrial Policy, competitiveness and SME), has requested to ENEA a research proposal dedicated to the remediation of contaminated sites as part of a larger program agreement, but such activities have not yet been funded.

\section{Acknowledgements}

Thanks to laboratory of Exploitation of Raw Materials and Groundwater Fluids, University of Rome "La Sapienza", the laboratory UTTPRA of ENEA and Prof V. Pascucci (University of Sassari) for invaluable support during sampling and characterization.

\section{References}

AUSILI A., CAPPUCCI S., GABELLINI M., INNOCENTI C., MAFFUCCI M., ROMANO E., ROSSI L., TARAMELLI A. (2012). New approaches for multi source data sediment characterisation, thickness assessment and clean up strategies. Chemical Engineering Transaction, Vol. 28, 6 p.

CAPPUCCI S., SCARCELLA D., ROSSI L., TARAMELLI A. (2011). Integrated Coastal Zone Management at Marina di Carrara Harbor: sediment management and policy making. Journal of Ocean and Coastal Management, Vol. 54, pp 277-289. http://dx.doi.org/10.1016/j.ocecoaman.2010.12.006

ERCOLE P. (2012). Rock wool production on industrial scale using bottom ash underproducts from solid waste incinirators. Rivista della Stazione Sperimentale del Vetro, Vol. 42 (2), p. 55-62.

FABRIZIO N. (2014). Il recupero dei sedimenti come materie prime nella produzione vetraria. Tesi sperimentale per la Laurea Magistrale in Ingegneria per l'Ambiente ed il Territorio, accademic year 2012-2013, 174 p. 